\title{
NorDiNa:
}

\section{En mångdimensionell nordisk tidskrift!}

Välkommen till NorDiNa nr 3! Vi i redaktionen är mycket glada över att innan NorDiNas första år är till ända kunna ge ut detta tredje nummer. Vi hoppas att vi får ert fortsatta förtroende genom att ni skickar oss vetenskapliga artiklar och rapporter från forskningsbaserade utvecklingsarbeten av intresse för vår nordiska publik. I NorDiNa presenterar vi också abstrakt från avhandlingar som publicerats i de olika nordiska länderna. Vi tar även in annonser från t.ex. förlag och konferenser av intresse för våra läsare. Tveka aldrig att höra av er till oss i redaktionen om ni har material som ni tror kan vara av intresse för NorDiNas läsare. Vi har ju hittills fått in artiklar så att de tre första numren kunnat fyllas med intressant läsning och vi har ett antal manuskript i olika faser av reviewprocessen inför nummer fyra. Vi vill dock passa på att uppmuntra er både att skicka in egna manuskript och stimulera kollegor att göra detta. Innan ett manuskript skickas till oss är det viktigt att läsa den författarvägledning som finns på insidan av bakre pärmen av denna tidskrift och utförligare på NorDiNas hemsida. Det har hänt vid några tillfällen att vi måst skicka tillbaka manuskript på grund av att det inte följt anvisningarna vad gäller t.ex. längden på manuskriptet som är satt till maximalt 8000 ord. Ytterligare en tjänst som vi ber om är att berätta om NorDiNa för alla de kollegor som ni tror skulle vara intresserade av vår tidskrift.

De två första numren av NorDiNa hade vi den stora glädjen att kunna dela ut gratis till alla intresserade. Vi tackar Anders Isnes och Naturfagsenteret, Oslo Universitet för denna generösa gåva. Från och med detta nummer skickas tidskriften ut enbart till våra prenumeranter. Därför ber vi er att då ni gör reklam för NorDiNa också informera om hur man blir prenumerant på tidskriften. Upplysningar om detta hittar ni i detta nummer på sidan 96 och på hemsidan: www.naturfagsenteret.no/tidsskrift/nordina

Mellan utgivningarna av nr 2 och nr 3 flyttade en av NorDiNas redaktörer, Berit Bungum, från Oslo till Trondheim. Hon har tillträtt en tjänst som førsteamanuensis vid Norges teknisk-naturvitenskapelige universitet, Institutt for Fysikk, Trondheim. Resten av redaktionen önskar Berit lycka till på den nya tjänsten och då vi vet att flytten skedde efter Berits egen önskan är vi glada för hennes skull. Det som gör oss extra nöjda är att Berit fortsätter som en av redaktörerna i NorDiNa. Berit har nu en ny e-postadress: berit.bungum@ntnu.no

Detta nummer av NorDiNa som du nu håller i din hand innehåller sex vetenskapliga artiklar från olika områden av vårt stora forskningsfält. Innehållet i artiklarna varierar i många olika dimensioner. En dimension är åldern på de elever eller studenter som ingår i studierna. Christel Persson behandlar i sin artikel "Nya former för lärande: Leken som ett redskap i lärandet i miljö i grundskolans tidigare årskurser" undervisning om näringskedjor och näringsvävar med nio år gamla elever. 
Hennes syfte med artikeln är att visa hur lek kan vara en dimension i undervisning och lärande i miljöfrågor. Eva Blomdahl exemplifierar sin teknikundervisningsidé i årskurs 6. Hennes artikel har titeln "Att undervisa i teknik - försök till en utbildningsfilosofi utifrån Heidegger och Dewey" och hon menar att det primära syftet med undervisning i teknik är att hjälpa elever att reflektera över teknik som ett socialt och kulturellt fenomen. Hon använder sig av idéer från Heidegger och Dewey i sin argumentation.

Lena Hansson och Andreas Redfors undersöker gymnasieelevers världsbild i sin artikel "Tre elever berättar om universum, gud och fysiken". Författarna är främst intresserade av vilka bidrag från fysik och från religion som eleverna ger i sina berättelser. Elever i samma ålder är i fokus för Erik Knain och Olav Prestvik i deras artikel "'Scientific literacy' nedfelt i geofagene" där de argumenterar för att det finns rika möjligheter att utveckla elevernas basfärdigheter då man undervisar i geografi för "scientific literacy" i närmiljön. I Espen O. Henriksens artikel "Aktiv og sosial læring i naturfag - utprøving av rollespill og teaching thinking i allmennlærerutdanninga" möter vi studenter i lärarutbildning. I artikeln argumenterar författaren för att s.k. "teaching thinking"-strategier och rollspel bidrar till att motivera studenter och elever i naturorienterande undervisning och dessutom ger det dem möjligheter att samtala om naturvetenskapliga frågor på sin egen kunskapsnivå. Astrid Sinnes' artikel "Three Approaches to Gender Equity in Science Education" behandlar pojkar och flickor på ett mer generellt plan. Författaren tar avstamp i feministisk teori då hon diskuterar hur olika kön/gender påverkar elevers närmande till naturvetenskap.

Artiklarna har alltså stor spännvidd när det gäller elevernas/studenternas ålder. En annan dimension är de olika ämnen som är representerade. Glädjande kan vi konstatera att i detta nummer finns både teknik och geografi med. Dessa ämnen har lite olika placering inom eller utanför de naturvetenskapliga skolämnena i våra olika nordiska länder. Detta medförde att vi speciellt skrev till teknik/teknologi och geografi i NorDiNas författarvägledning. Förutom teknik och geografi finns i detta nummer artiklar som behandlar delar av fysik och biologi vid sidan av naturvetenskapligt innehåll mer generellt.

Även denna gång presenterar vi förutom vetenskapliga artiklar ett kortare informativt bidrag med titeln "Curriculum development and projects". Sonja M. Mork skriver om den Internetbaserade undervisningsresursen "viten.no"; vilka program som är tillgängliga, hur de har utvecklas och hur mycket de används. Vi välkomnar denna typ av bidrag i NorDiNa, som vi tror underlättar utbytet av idéer och resurser mellan våra grannländer. Dessa bidrag gör det också möjligt att få kännedom om utvecklingen inom området undervisning och lärande i naturvetenskap inklusive teknik/teknologi och geografi i de nordiska länderna.

Ytterligare en dimension är de länder som är representerade. Vi eftersträvar att ha bidrag från helst varje nordiskt land eller så många som möjligt i varje nummer av NorDiNa. I nummer 1 hade vi bidrag från Danmark, Finland, Norge och Sverige; i nummer 2 från Finland, Norge och Sverige och nu i nummer 3 enbart från Norge och Sverige. Vi önskar bryta denna trend och hoppas på din hjälp att uppmuntra våra kollegor runt hela Norden och varför inte även från andra länder att skicka in manuskript till oss i NorDiNa.

God skrivning och läsning!

Med hälsning från redaktörerna,

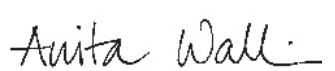

Anita Wallin

Göteborgs universitet

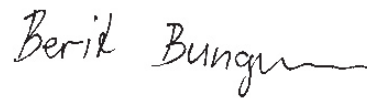

Berit Bungum

Universitetet i Oslo
Byom Andersm

Björn Andersson

Göteborgs universitet 